\title{
An Immunological Investigation of Leaf Development in Capsicum frutescens
}

\author{
Jalal Omer Ahmed ${ }^{1}$, Sarkaut Salimi ${ }^{2} \&$ Anwar Rashid Abdulla ${ }^{1}$ \\ ${ }^{1}$ Industrial Crops Department, Agricultural Technical Institute of Bakrajo, Sulaimani, Iraq \\ ${ }^{2}$ Department of Agriculture, Payame Noor University, Tehran, Iran \\ Correspondence: Sarkaut Salimi, Department of Agriculture, Payame Noor University, PO BOX 19395-3697, \\ Tehran, Iran. E-mail: sarkaut1983@gmail.com
}

Received: February 6, 2013 Accepted: March 5, 2013 Online Published: April 15, 2013

doi:10.5539/jas.v5n5p66 URL: http://dx.doi.org/10.5539/jas.v5n5p66

\begin{abstract}
The objective of this project was to investigate the developmental regulation of cell wall components and development of leaves of Capsicum frutescens. In order to this, a growth curve was constructed of lengths and widths of fifty Capsicum frutescensleaves measured until growth had stopped (20 days). From the curve, four developmental stages were selected and harvested for further study. Cell wall proteins from each developmental stage were then extracted. The protein concentration present in each selected stage was then calculated from a Bovine Serum Albumin (BSA) standard curve. Then an immunological (Immunodot Blots) study was carried out to detect various cell wall associated epitopes present in the extracts.
\end{abstract}

Keywords: Capsicum frutescens, immunological, leaf development

\section{Introduction}

The Capsicum genus belongs to the family Solanaceae. Species of Capsicum are used as condiments, spices, ornamentals and in pharmaceutical therapies. Capsicums are native to South America and are cultivated in warm, dry climatic conditions, but cannot tolerate frost (Barceloux, 2008; Lozzio et al., 2008). The term Capsicum is believed to be derived from Greek word 'Kapsimo' which means bite (in terms of taste). Globally Capsicum is called by a variety of names e.g. pepper, chilli, chile, cayenne, paprika, aji, jalapeno, pimento, sweet pepper or bell pepper, red and green peppers (Kothari et al., 2010; Sanatombi et al., 2010). The genus Capsicum includes around 25 wild and 5 domesticated species. Worldwide, Capsicum annuum was the first pepper to be introduced (Siviero, 2002). Capsicum species are basic ingredients in many cuisines as a flavourant, colourant and to add taste (Ravishankar et al., 2003; Kothari et al., 2010). According to Kelly and Kelly (2001), chillies have been used since $3400 \mathrm{BC}$ for domestic purposes. Hence, it is one of the oldest cultivated crops (Wallin, 2004). Globally, chillies were spread via colonisation mainly by the Portuguese. The Portuguese started establishing their colonies in India in the 16th century and by 1512 had established a chilli trade in all major cities of India. Chillies are thought to have introduced to China by Buddhist monks and from India to Srilanka (Wallin, 2004). The leaf plays an important role during plant development and is the main centre of photosynthesis and respiration. The leaf consists of the blade or lamina, stalk (petiole), nodes, axils (Becky, 2004). Leaf development consists of five phases. In phase I, leaf position is determined. Phase II determines leaf length, phase III, determines leaf width, phase IV determines leaf enlargement and phase-V determines leaf thickness. Meristematic tissue therefore regulates both leaf shape and size. The leaf in the early stages of morphogenesis is termed the 'primordium'. The shoot apical meristem (SAM) gives rise to leaf primordia in a regular pattern, with a definite position and arrangement according to the phyllotoxy (Byrne, 2005). Morphologically, scientists have classified two types of leaves- microphyllls and megaphylls. Microphylls are present in lycophytes and horsetails and are lacking complex venation patterns and parenchymatous tissues. Megaphylls have larger larger leaves, complex venation as in ferns and higher plants (euphyllotypes) (Piazza et al., 2005). 


\section{Material and Methods:}

\subsection{Plant Materials}

The chilli pepper plants (C. frutescens) used in this investigation were grown under greenhouse conditions consisting of 16 hours of light and 8 hours of dark at temperatures of between 15 to $25^{\circ} \mathrm{C}$ from April to August 2011.

\subsection{Growth Curve and Chilli Leaf Harvestion}

The lengths and widths of fifty Capsicum frutescens (chilli) young leaves were measured and recorded on a daily basis. The chilli leaves were measured starting from lengths of 30, 31, and 32 and widths of 11, 12 and 13 until they reached their full length (growth had stopped or slowed significantly). Two growth curves were then constructed using average lengths and widths of the chilli leaves and used to select four different developmental stages of growth for further study. The chilli leaves from the selected stages were then harvested and $30 \mathrm{mg}$ of chilli leaves from each stage was placed into Eppendorf tubes, labelled and stored at $-20^{\circ} \mathrm{C}$.

\subsection{Extraction of Cell Wall Proteins from Chilli Leaves}

$200 \mu \mathrm{l}$ of extraction buffer (Appendix 1) was added to the Eppendorf tubes containing $30 \mathrm{mg}$ of chilli leaves and homogenised (by using Eppendorf grinder). The samples were then centrifuged at 13,000 rpm for 5 minutes and the supernatant transferred into a fresh sterile Eppendorf tube and the pellet discarded. This step was repeated. $800 \mu \mathrm{l}$ of absolute ethanol $(80 \% \mathrm{v} / \mathrm{v})$ was added to each of the $200 \mu \mathrm{l}$ samples to precipitate out carbohydrates (cellulose, hemicelluloses, pectin) and heavily glycosylated glycoproteins extensions (hydroxyproline-rich glycoproteins, HRGP) and arabinogalactin proteins (AGP's)]. The sample was then incubated overnight at $4^{\circ} \mathrm{C}$. The precipitated sample was centrifuged again at 13,000 rpm for 10 minutes. The supernatant was discarded and the pellet was re-suspended in $100 \mu \mathrm{l}$ of sterile distilled water (SDW). The protein extract was stored at $-20^{\circ} \mathrm{C}$, prior to future usage.

\subsection{Protein Assay}

$2 \mu \mathrm{l}$ of each of the protein samples (stage 1 - 4) were placed into a $1.5 \mathrm{ml}$ Eppendorf tube with $798 \mu \mathrm{l}$ of SDW to make a 400X dilution. $200 \mu \mathrm{l}$ of BIORAD dye reagent was added to each tube and mixed by gentle inversion of the Eppendorf tubes. $800 \mu \mathrm{l}$ of SDW and $200 \mu \mathrm{l}$ of BIORAD dye reagent was put into another Eppendorf tube and used as a control. After 10 minutes, the samples were transferred to cuvettes and the optical density of each of the samples was measured using a spectrophotometer. The absorbance for the samples was read at $595 \mathrm{~nm}$, using the control as a blank. The absorbance of each protein samples was then compared to a standard absorbance curve for Bovine Serum Albumin (BSA) (Appendix 3, Table.7) to determine the protein concentration for each sample (Bio-Rad laboratories, 2005).

\subsection{Immuno-Dot Blots}

The protein samples from the four stages were diluted to the lowest protein concentration $(1 \mu \mathrm{g} / \mu \mathrm{l})$ by the addition of sterile distilled water. A $1 \mathrm{~cm}$ grid was then drawn onto nitrocellulose membrane and cut into $1 \mathrm{~cm} \mathrm{x}$ $6 \mathrm{~cm}$ rectangles. One square was cut diagonally to indicate the position of the four different stages. $1 \mathrm{ug}$ of each protein sample was dotted onto the nitrocellulose membrane and $1 \mu 1$ of SDW was used as a negative control. These strips of nitrocellulose membrane were then left to air dry for 30 minutes. The strips of nitrocellulose membrane were then soaked in 1 x TBS pH 7.4 (Appendix 2) for 5 minutes and then a blocking solution consisting of a $5 \%$ solution of skimmed milk powder in $10 \mathrm{ml}$ of $1 \times$ TBS was added to the membranes and left for one hour on an orbital shaker at room temperature. $200 \mu \mathrm{l}$ of the primary antibody (1:4 dilutions) was added to the membranes in the blocking solution and then left for further 2 hours on the orbital shaker at room temperature. The membranes were subsequently washed four times in $1 \mathrm{x}$ TBS for five minutes each time. After the membranes were washed, another $10 \mathrm{ml}$ of blocking solution was added and then $10 \mu \mathrm{l}$ of secondary antibody (goat anti-rat IgG alkaline phosphatase conjugate) was added to the membranes (1: 1000 dilution) and returned to the orbital shaker for 1 more hour. The membranes were then given $5-6$ minutes washes in 1x TBS and this step was repeated three times. $10 \mathrm{ml}$ of alkaline phosphate buffer (Appendix 2) containing $66 \mu \mathrm{l}$ of nitro blue tetrazolium (NBT) and $33 \mu 1$ of 5-bromo-4-chloro-3-indolyl-phosphatase (BCIP) was added to the membranes to detect bound antibodies. The membranes were then observed, while they developed. Once the dots had fully developed, the membranes were rinsed in SDW and left to air dry on a filter paper. Then the membranes were photographed. 


\section{Results}

\subsection{Growth Curve for Chillileaves}

The standard deviations for leaf length are calculated. From the growth curve, four developmental stages were selected for the further experiments (Table 1)
1) Days $3(40 \pm 2.73 \mathrm{~mm})$-stage 1 ,
2) Days $6(60 \pm 3.9 \mathrm{~mm})$-stage 2 ,
3) Days $9(80 \pm 7.58 \mathrm{~mm})$-stage 3 and
4) Days $18(114.1 \pm 8.74 \mathrm{~mm})$-stage 4.

Table 1. Stages of Capsicum frutescens leaf development selected for further study

\begin{tabular}{ccccc}
\hline Stage & $\begin{array}{c}\text { No. of days of growth } \\
\text { (from, 30, 31,32) }\end{array}$ & $\begin{array}{c}\text { Mean } \\
(\mathrm{mm})\end{array}$ & $\begin{array}{c}\text { Standard Deviation } \\
( \pm)\end{array}$ & $\begin{array}{c}95 \% \text { Confidence Intervals } \\
(\mathrm{mm})\end{array}$ \\
\hline 1 & 3 & 40 & 2.73 & $\pm 38-42$ \\
2 & 6 & 60 & 3.9 & $\pm 58-62$ \\
3 & 9 & 80 & 7.58 & $\pm 78-82$ \\
4 & 18 & 114.1 & 8.74 & $\pm 110-120$ \\
\hline
\end{tabular}

Table 2. Protein concentration of samples from the absorbance readings plotted against BSA standard curve

\begin{tabular}{|c|c|c|c|c|c|}
\hline Tube No. & $\begin{array}{l}\text { Sample } \\
\text { stage }\end{array}$ & $\begin{array}{l}\text { Absorbance } \\
(595 \mathrm{~nm})\end{array}$ & Mean & $\begin{array}{l}\text { Protein concentration from graph } \\
(\mu \mathrm{g} / \mu \mathrm{l})\end{array}$ & $\begin{array}{l}\text { Protein concentration of sample } \\
(\mu \mathrm{g} / \mu \mathrm{l})\end{array}$ \\
\hline \multirow{2}{*}{1} & \multirow{2}{*}{1} & 0.274 & \multirow{2}{*}{0.282} & \multirow{2}{*}{4} & \multirow{2}{*}{2} \\
\hline & & 0.290 & & & \\
\hline \multirow{2}{*}{2} & \multirow{2}{*}{2} & 0.454 & \multirow{2}{*}{0.451} & \multirow{2}{*}{10} & \multirow{2}{*}{4} \\
\hline & & 0.448 & & & \\
\hline \multirow{2}{*}{3} & \multirow{2}{*}{3} & 0.672 & \multirow{2}{*}{0.667} & \multirow{2}{*}{17.5} & \multirow{2}{*}{7} \\
\hline & & 0.662 & & & \\
\hline \multirow{2}{*}{4} & \multirow{2}{*}{4} & 0.457 & \multirow{2}{*}{0.454} & \multirow{2}{*}{10} & \multirow{2}{*}{4} \\
\hline & & 0.451 & & & \\
\hline
\end{tabular}

\subsection{Protein Assay}

A Bovine Serum Albumin standard curve was plotted to determine the protein concentrations of various samples pertaining to stages 1 to 4 . From the four stages, absorbance values were read at the wavelength $595 \mathrm{~nm}$. The samples were then diluted to a concentration of $1 \mu \mathrm{g} / \mu \mathrm{l}$ for the further studies. The absorbance values were read for twice and the average plotted against the standard Bovine Serum Albumin curve and the concentration of protein samples the determined.

\subsubsection{Dilution Factor Correction}

1) From the stage1, mean absorbance value obtained was 0.282 read at $595 \mathrm{~nm}$ (Table 2). This absorbance value within the protein concentration $4 \mu \mathrm{g} / \mu \mathrm{l}$. As this sample was diluted to 400 times, it had to be converted to dilution factor to arrive at protein concentration of sample stage 1 as follows.

$$
4 / 1000 \text { x } 400=1.6 \mu \mathrm{g} / \mu \mathrm{l} \approx 2 \mu \mathrm{g} / \mu \mathrm{l}
$$

2) From the stage 2, mean absorbance value obtained was $0.451 \mathrm{read}$ at $595 \mathrm{~nm}$ (Table 2). This absorbance value within the protein concentration $10 \mu \mathrm{g} / \mu \mathrm{l}$. As this sample was diluted to 400 times, it had to be converted to dilution factor to arrive at protein concentration of sample stage 2 as follows.

$$
10 / 1000 \times 400=4 \mu \mathrm{g} / \mu \mathrm{l}
$$


3) From the stage 3, mean absorbance value obtained was 0.667 read at $595 \mathrm{~nm}$ (Table 2). This absorbance value within the protein concentration $17.5 \mu \mathrm{g} / \mu \mathrm{l}$. As this sample was diluted to 400 times, it had to be converted to dilution factor to arrive at protein concentration of sample stage 3 as follows.

$$
17.5 / 1000 \times 400=7 \mu \mathrm{g} / \mu \mathrm{l}
$$

4) From the stage 4, mean absorbance value obtained was 0.454 read at $595 \mathrm{~nm}$ (Table 2). This absorbance value within the protein concentration $10 \mu \mathrm{g} / \mu \mathrm{l}$. As this sample was diluted to 400 times, it had to be converted to dilution factor to arrive at protein concentration of sample stage 4 as follows.

$$
10 / 1000 \times 400=4 \mu \mathrm{g} / \mu \mathrm{l}
$$

\subsection{Immuno-Dot Blots}

Immuno-dot blots were carried out to detect the presence of epitopes present in the leaf cell wall extracts from developmental stages 1 to 4. Primary monoclonal antibodies named JIM-5, 7, 8; LM-5 and 6 were used for epitopes detection (Table 4). These blots were performed in duplicate and the results analysed on the basis of an intensity of epitopes. In the tables 4and 5, a high intensity is represented in terms of ' + ' signs. As the ' + ' signs increase, the intensity kindly increase. High intensity represented high binding levels of the specific primary antibody to the epitopes. The variations in the intensities of different samples infer that epitopes were developmentally regulated.

\begin{tabular}{|c|c|c|c|c|c|}
\hline Antibody Used & & & & & \\
\hline \multirow[t]{2}{*}{ JIM 5} & Control & Sample 1 & Sample 2 & Sample 3 & Sample 4 \\
\hline & $1 \mu l$ & $1 \mu 1$ & $1 \mu l$ & $1 \mu l$ & $1 \mu 1$ \\
\hline \multirow[t]{2}{*}{ JIM7 } & Control & Sample 1 & Sample 2 & Sample 3 & Sample 4 \\
\hline & $1 \mu 1$ & $1 \mu l$ & $1 \mu l$ & $1 \mu 1$ & $1 \mu 1$ \\
\hline \multirow[t]{2}{*}{ JIM8 } & Control & Sample 1 & Sample 2 & Sample 3 & Sample 4 \\
\hline & $1 \mu 1$ & $1 \mu l$ & $1 \mu 1$ & $1 \mu 1$ & $1 \mu 1$ \\
\hline \multirow[t]{2}{*}{ LM5 } & Control & Sample 1 & Sample 2 & Sample 3 & Sample 4 \\
\hline & $1 \mu 1$ & $1 \mu l$ & $1 \mu 1$ & $1 \mu l$ & $1 \mu 1$ \\
\hline \multirow[t]{2}{*}{ LM6 } & Control & Sample 1 & Sample 2 & Sample 3 & Sample 4 \\
\hline & $1 \mu 1$ & $1 \mu l$ & $1 \mu 1$ & $1 \mu \mathrm{l}$ & $1 \mu \mathrm{l}$ \\
\hline
\end{tabular}

Table 3. Samples dotting on nitrocellulose membrane with control upon specific antibody

\begin{tabular}{|c|c|c|c|c|c|c|c|c|}
\hline \multirow{2}{*}{ No. } & \multirow{2}{*}{$\begin{array}{l}\text { Antibody } \\
\text { Used }\end{array}$} & \multirow{2}{*}{ Replicates } & \multicolumn{5}{|c|}{ Leaf Stages } & \multirow{2}{*}{$\begin{array}{l}\text { Intensity } \\
\text { observation }\end{array}$} \\
\hline & & & 1 & 2 & 3 & 4 & Control & \\
\hline \multirow{2}{*}{1} & \multirow{2}{*}{ JIM 5} & 1 & ++ & ++ & +++ & ++++ & - & \multirow{2}{*}{ Increasing } \\
\hline & & 2 & ++ & ++ & +++ & ++++ & - & \\
\hline \multirow{2}{*}{2} & \multirow{2}{*}{ JIM7 } & 1 & ++ & + & + & + & - & \multirow{2}{*}{ Decreasing } \\
\hline & & 2 & ++ & + & + & + & - & \\
\hline \multirow{2}{*}{3} & \multirow{2}{*}{ JIM8 } & 1 & +++ & +++ & +++ & +++ & - & \multirow{2}{*}{ No Change } \\
\hline & & 2 & +++ & +++ & +++ & +++ & - & \\
\hline \multirow{2}{*}{4} & \multirow{2}{*}{ LM5 } & 1 & +++ & ++ & ++ & ++ & - & \multirow{2}{*}{ Decreasing } \\
\hline & & 2 & ++ & ++ & ++ & ++ & - & \\
\hline \multirow{2}{*}{5} & \multirow{2}{*}{ LM6 } & 1 & +++ & +++ & +++ & +++ & - & \multirow{2}{*}{ No Change } \\
\hline & & 2 & +++ & +++ & +++ & +++ & - & \\
\hline
\end{tabular}

Table 4. Summary of Immuno dot blots intensity for the four developmental stages

(+ Low intensity, ++ Medium intensity, +++ High intensity, ++++ Very high intensity, - No binding).

According to obtained results, average intensities to each sample were calculated to observe the intensity levels of the antibodies expression (Table 4). 
Table 5. Average intensity to each blot sets

\begin{tabular}{llllllll}
\hline \multirow{2}{*}{ No. } & \multirow{2}{*}{ Antibody Used } & \multicolumn{7}{c}{ Average Intensity (Leaf Stages) } & \multirow{2}{*}{ Intensity observation } \\
\cline { 2 - 6 } & & 1 & 2 & 3 & 4 & Control & \\
\hline 1 & JIM 5 & ++ & ++ & +++ & ++++ & - & Increasing \\
2 & JIM7 & ++ & + & + & + & - & Decreasing \\
3 & JIM8 & +++ & +++ & +++ & +++ & - & No Change \\
4 & LM5 & +++ & ++ & ++ & ++ & - & Decreasing \\
5 & LM6 & +++ & +++ & +++ & +++ & - & No Change \\
\hline
\end{tabular}

(+ Low intensity, ++ Medium intensity, +++ High intensity, ++++ Very high intensity, - No binding)

Samples 1 to 4 developmental stages expressed epitope conveyed the presence of cell wall epitopes in all the samples. JIM 7 and LM 5 antibodies expressed in first blot and inferred that these epitopes were developmentally regulated. In general, JIM 5 (John Innes monoclonal antibody-JIM) binds to pectin and recognizes partially methyl esterified epitopes of homogalacturone and unesterified homogalacturone. JIM 7 recognises methyl esterified pectin. Hence it detects methyl esterified pectic in sample 1 . LM 5 recognises beta-D galactone epitopes in sample one and the intensity decreasing from second to fourth sample. This inferred that the samples were developmentally regulated. JIM 8 recognises arabinogalactans (AG) and AG detects in sample 1 to 4 without any change in intensity. Immuno-dot blot results are shown in figure 1 to 5 according to each epitopes respectively (JIM 5, 7, 8 and LM 5 \& 6 with control).

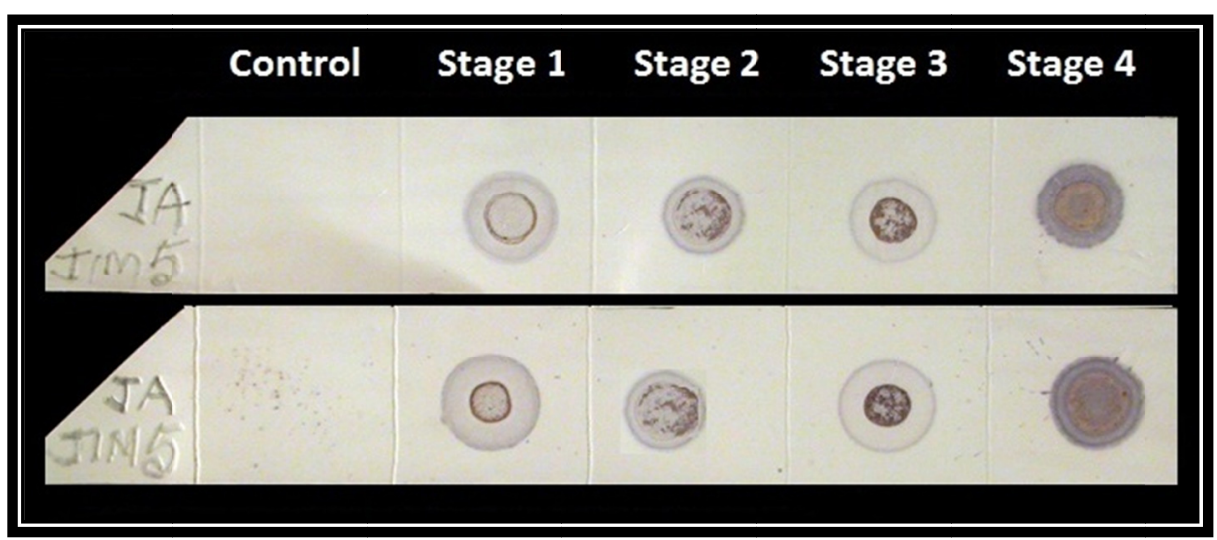

Figure 1. Photograph of Immunodot-blot for JIM5

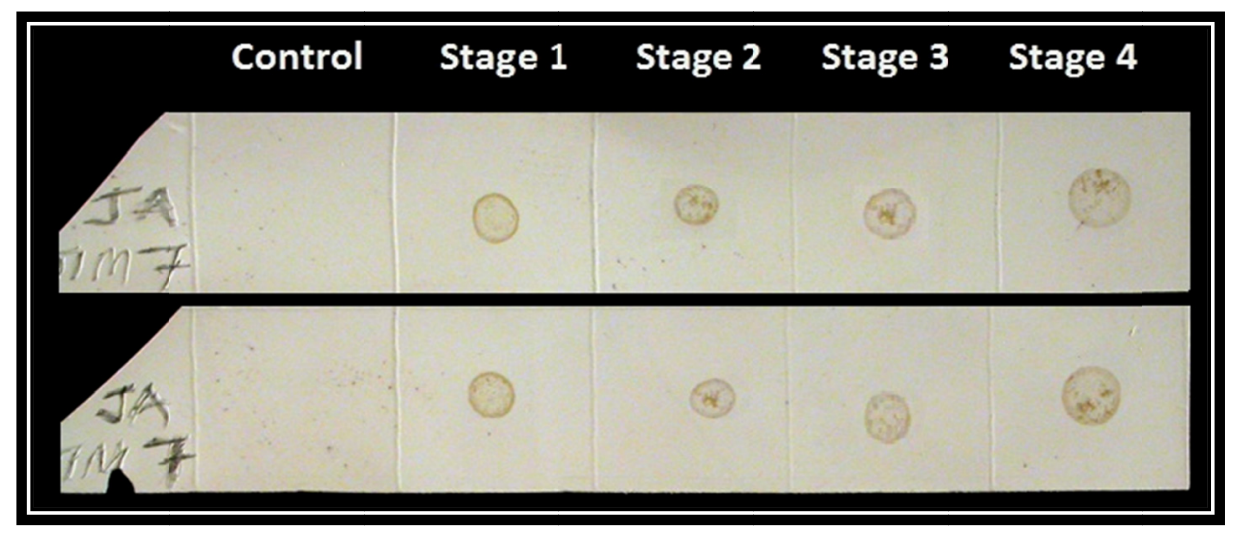

Figure 2. Photograph of Immunodot-blot for JM7 


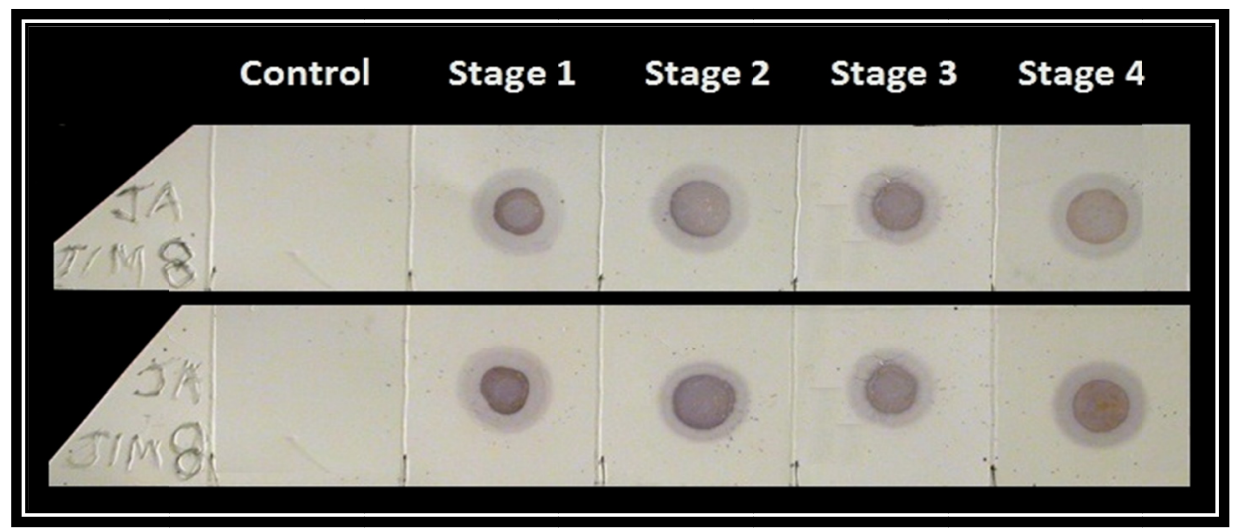

Figure 3. Photograph of Immunodot-blot for JM8

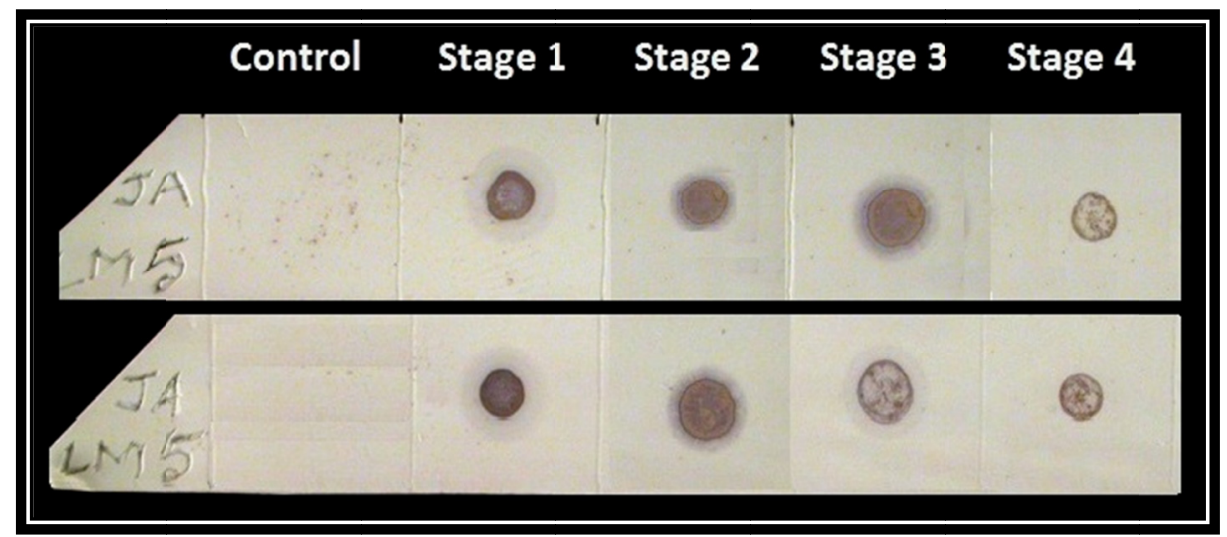

Figure 4. Photograph of Immunodot-blot for LM5

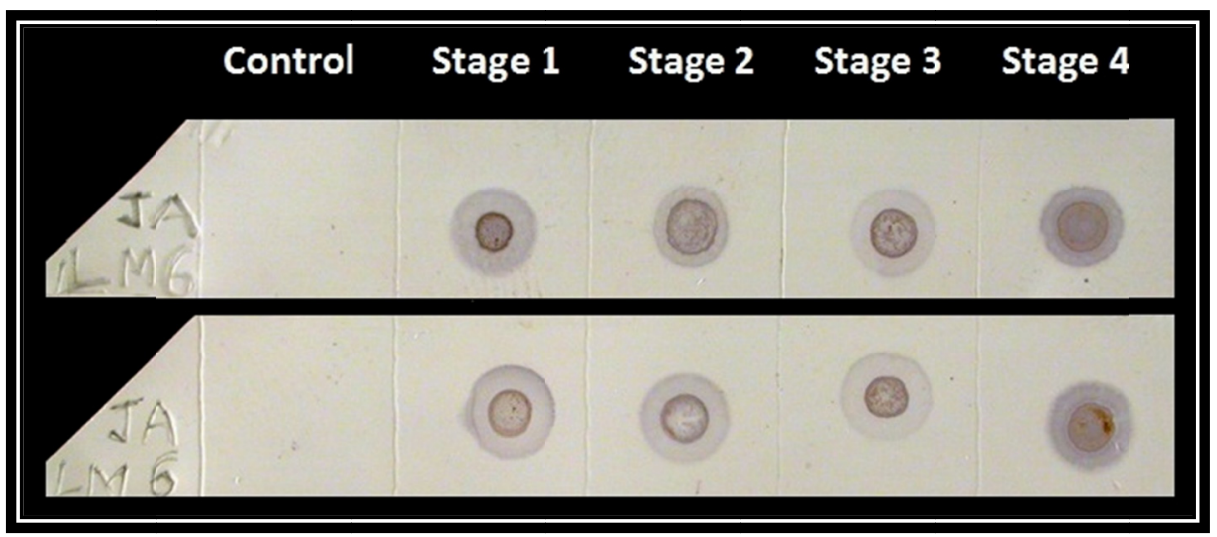

Figure 5. Photograph of Immunodot-blot for LM6

As per the results obtained, the four samples expressed various antibodies finely and conveyed that the epitopes were developmentally regulated according to their respective stages.

\section{Discussion}

Leaf is a principle organ of photosynthesis, respiration and is divided into different portions like blade and petiole-stalk. Leaf is responsible for photosynthesis (food manufacture) and respiration (usable energy production). Leaves are the repositories of food and water (Tsukaya, 2002). In response to environmental conditions, leaves themselves modified to various kind of forms to sustain. Leaves are used in multidiscipline fields like food, medicine, fossil fuel and many (Lozzio et al., 2008; Ravishankar et al., 2003). Capsicum is a crop having economic importance around the globe especially in the countries like India, Mexico and China. 
immunological techniques were performed to investigate developmental changes occur in cell wall composition in leaves of Capsicum frutescens according to their developmental selective stages. Studies pertaining to crystallography, spectroscopy, microscopic analyses and many are the basis for cellulose structure elucidation in the cell walls of the plants. Analytical tools like IR (Infra Red), NMR (Nuclear Magnetic Resonance), XRD (X-ray Diffraction), TEM (Transmission Electron Microscopy) and Atomic Force Microscopy (AFM) are providing atomic level resolutions of cellulosic matrix present in the cell wall of plant tissues (Harris et al., 2010). Pectic components of cell wall are identified by monoclonal antibodies which are highly efficient and reliable. In the cell walls of higher plants, pectins are major components that play a key role in cell adhesion (Jones et al., 1997). From the results it can be concluded that JIM5, JIM7 and LM5 epitopes were developmentally regulated and the functions of each epitope were depicted in tabular form (Table 6).

Table 6. Panel of Monoclonal antibodies used in Immuno dot blots

\begin{tabular}{lll}
\hline Monoclonal Antibodies & Epitopes Recognised & Reference \\
\hline JIM 5 & Anti- Homogalacturonan (unsterified pectin) & Knox et al., 1990 \\
JIM 7 & Anti- Homogalacturonan (methyl esterifed pectin) & Willats et al., 2000 \\
JIM 8 & Arabinogalactans & Yi-qin et al., 2004 \\
LM 5 & Anti- $\beta$ - 1, 4-D- Galactan & Knox, 2008 \\
LM 6 & Anti- $\alpha$ - 1, 5- D- Arabinan & Seifert \& Roberts, 2007 \\
\hline
\end{tabular}

JIM5 detected unesterifiedpectins present in the samples. As JIM7 expressed in decreasing order with a higher intensity in the stage 1, inferring that the four developmental stages detected methyl un-esterified pectins and were developmentally regulated. LM5 recognised $\beta$-D-Galactan with higher intensity in stage 1 and the intensities were decreased from stage 1 to 2 and from the $2^{\text {nd }}$ stage, intensities were stable as no change was observed. The epitopes of JIM8 and LM6 were recognised but the intensity observation remained the same without any detectable change. These results conveyed that the stages from 1 to 4 were developmentally regulated.

In primary cell walls, celluloses and hemicelluloses are the prime polysaccharides. Structurally celluloses comprising of 1, 4- $\beta$-D-glucose residues and hemicelluloses are branched polysaccharides and are homologous to celluloses as their backbone is composed of 1, 4 linked $\beta$-D-Hexosy-1-residue. In primary cell walls, the abundant hemicelluloses present are xyloglucans. Gluronoxylan, arabinoxylan, glucomannan and galactomannan are the other hemicelluloses present in the secondary cell wall (Brett \& Waldron, 1996).

\section{Conclusion}

Capsicum frutescensis an important agro-economic crop which could benefit from the research to improve quality, yields and production levels by using the various plant biotechnological methods. Solanaceae members such as L. esculentum (tomato), $N$. tobaccum (tobacco) and S. tuberosum (potato) are the model systems have been subjected to biochemical and immunological investigations (Ochoa-Alejo \& Ramirez-Malagon, 2001). Advanced techniques such as genetic transformation, genetic modification can improve the crop qualities and these crop cells are capable of regenerating organs by cell, tissue and organ cultures and eventually to a whole plant in vitro.

According to a study done by Ochao-Alejo and Ramirez-Malagon (2001) conferring resistance to pests and diseases to the plants is highly difficult by recombinant DNA techniques. Till now, much progress has been done in terms of genetic improvement of Capsicum. Still a long way is ahead to improve the quality traits. Many efforts are being put to combat various kinds of diseases especially viral induced diseases. But these efforts are still not satisfactory. Various strategies have been employed to protect plants against viruses such as protein mediated resistance and satellite RNA mediated resistance. To block the progress of virus infection, protein based approaches are reliable.

In RNA based resistance, viral DNA is degraded by using plants post-transcriptional gene silencing mechanism. Advanced technique like designing artificial microRNA (miRNA) is used against pathogenic viruses. Artificial miRNA down regulates the gene expression in plants. So this technique is exploited to confer resistance in plants to combat against pathogenic virus (Kothari et al., 2010). 
A variety of investigative techniques such as immuno dot blots have depicted the presence and importance of developmentally regulated cell wall associated proteins. Further research work is mandatory to identify, diagnose and their role in the developmental regulation of proteins and synthesis of new cell wall components.

It could be quite inevitable that all the new cell wall proteins and their genes must be identified and characterised. But the difficulty here is their functions and molecular interactions. Prior to their function, knowing the protein position is a million dollars question. Inculcating mutants by antisense RNA technology is exciting but is a difficult experiment and is raising many concerns regarding ethics. So these concerns must be answered in the upcoming days (Showalter, 1993).

\section{References}

Barceloux, D. G. (2008). Medical toxology of Natural substances: foods, fungi, Medicinal herbs. Toxic plants and venomous animals, 71-76. Hoboken, N. J: John Viley and sons Inc.

Becky, E. (2004). Plants and their Structure, Leaves. Retrieved 27th August, 2010, from http://www.cartage.org.lb/en/themes/sciences/BotanicalSciences/PlantsStructure/Leaves/Leaves.htm

Bio-Rad laboratories. (2005). Instruction for the bio-rad protein assay. Retrieved from http://www.bio-rad.com

Brett, C. T., \& Waldron, K. W. (1996). Physiology and Biochemistry of cell walls (2nd ed.). London: Chapman and Hall.

Byrne, M. E. (2005). Networks in Leaf development. Current opinion in Plant Biology, 8, 59-66.

Harris, D., Bulone, B., Ding, S. Y., \& DeBolt, S. (2010). Tools for Cellulose Analysis in Plant Cell Walls. Plant Physiology, 153, 420-426.

IBPGR. (1983). Genetic Resources of Capsicum. Rome: International Board for Plant Genetic Resources.

Jones, L., Seymour, G., \& Knox, J. (1997). Localisation of PecticGalactan in Tomato Cell walls using a Monoclonal Antibody specific to [1-4]- $\beta$-D-galactan. Plant Physiology, 113, 1405-1412.

Kelly, J., \& Kelly, J. (2001). An Archaeological guide to Central and South Mexico. Oklahoma: University.

Kothari, S. L., Joshi, A., kachhwaha, S., \& Ochoa-Alejo, N. (2010). Chilli peppers-A review on tissue culture and transgenesis. Biotechnology advances, 28(2010), 35-48.

Lozzio, M., Tundis, R., Menichini, F., Statti, G., \& Menichini, F. (2008). Influence of ripening stage on Health Benefits Properties of Capsicum annuum Var. Acumunatum L.: In vitro Studies. Journal of Medicinal Food, 11(1), 184-189.

Ochoa-Alejo, N., \& Ramirez-Malagon, R. (2001). In vitro chilli pepper biotechnology. Bio plant, 37, 701-729.

Piazza, P., Jasinski, S., \& Tsiantis, M. (2005). Evolution of leaf developmental mechanisms. New Phytologist, 167, 693-710.

Ravishankar, G. A., Suresh, B., Giridhar, P., Rao, S. R., \& Johnson, T. S. (2003). Biotechnological studies on Capsicum metabolite production and plant improvement. In De AK, Capsicum: The genus of Capsicum. London: CRC press.

Sanatombi, K., Sen-Mandi, \& Sharma, G. J. (2010). DNA profiling of Capsicum landraces of Manipur. Scientia Horticulturae, 124(2010), 405-408.

Showalter, A. M. (1993). Structure and function of plant cell wall proteins. Review the Plant Cell, 5, 9-23.

Siviero, P. (2002). Agricultural, chemical and genetic profiles of hot peppers. Molecular Nutrition and Food Research, 72, 53-72.

Tsukaya, H. (2002). Leaf Development: The Arabidopsis Book. American Society of Plant Biologists. Retrieved 15th August, 2010, from http://www.bioone.org/doi/pdf/10.1199/tab.0072

Wallin, N. (2004). Chilli: A small fruit that sets global palettes on fire. Retrieved 17th August, 2010, from http://yaleglobal.yale.edu/about/chilli.jsp 


\section{Appendix 1: Cell wall extraction buffers}

Stock solutions

A - 0.5 M EDTA (500 ml)

93g of dissodium EDTA-2H20

Dissolved slowly in $400 \mathrm{ml}$ of SDW

Adjust $\mathrm{pH}$ to 8.0 with approximately $10 \mathrm{~g}$ of $\mathrm{NaOH}$ pellets

B - $2 \mathrm{M} \mathrm{NaCI}(100 \mathrm{ml})$

$11.2 \mathrm{~g} \mathrm{NaCI}$

Dissolved in $100 \mathrm{ml} \mathrm{SDW}$

Autoclave

C - 1 M Tris-HCl pH $8.0(100 \mathrm{ml})$

$12.11 \mathrm{~g}$ Tris base

Dissolved in $80 \mathrm{ml} \mathrm{SDW}$

Adjust $\mathrm{pH}$ with Concentrated HCI

Autoclave

Protein extraction buffer

A-10 mM EDTA

B-10 $\mathrm{mMNaCl}$

C- 0.2 M Tris- $\mathrm{HCl}$ (pH 8.0)

For preparing $1 \mathrm{ml}$ protein extraction buffer

$200 \mu \mathrm{l}$ 1M Tris-HCl (pH 8.0)

$5 \mu 12 \mathrm{M} \mathrm{NaCl}$

$20 \mu 10.5 \mathrm{M}$ EDTA

$775 \mu 1$ SDW

$1 \mathrm{ml}$ Extraction buffer

$900 \mu 1$ Proteinextraction buffer

$100 \mu 1$ 10\% Nonidet

$1 \mu \mathrm{M}$ DTT

\section{Appendix 2: Immuno-dot blots Solutions}

$10 \mathrm{x}$ TBS (Tris buffered saline) $(500 \mathrm{ml})$

$40 \mathrm{~g} \mathrm{NaCl}$

$1 \mathrm{~g} \mathrm{KCI}$

$15 \mathrm{~g}$ Tris base

Dissolve in $300 \mathrm{ml}$ of SDW

Adjust $\mathrm{pH}$ to 7.4 with concentrated HCI

Make up volume to $500 \mathrm{ml}$ with SDW

Autoclave

Alkaline phosphate buffer $(500 \mathrm{ml})$

$2.5 \mathrm{ml} 1 \mathrm{M}$ Tris- $\mathrm{HCl} \mathrm{pH} 9.5$

$2.92 \mathrm{~g} \mathrm{NaCl}$

$0.508 \mathrm{~g} \mathrm{MgCl} 2$

Make up volume to $500 \mathrm{ml}$ with SDW 


\section{Appendix 3: BovineSerumAlbumin (BSA) proteinassay}

Table 7. BovineSerum Albumin (BSA) protein assay

\begin{tabular}{|c|c|c|c|c|c|c|}
\hline Tube & $\begin{array}{l}\text { Final BSA protein } \\
\text { concentration } \\
(\mu \mathrm{g} / \mu \mathrm{l})\end{array}$ & $\begin{array}{l}\text { Volume of } \\
\text { Stock }(\mu \mathrm{g})\end{array}$ & $\begin{array}{c}\text { BIORAD dye } \\
\text { Reagent } \\
(\mu 1)\end{array}$ & $\begin{array}{l}\text { Volume of } \\
\text { SDW }(\mu 1)\end{array}$ & $\begin{array}{c}\text { Absorbance } \\
(595 \mathrm{~nm})\end{array}$ & Mean \\
\hline 1 & 1 & 2 & 200 & 1798 & $\begin{array}{l}0.116 \\
0.122\end{array}$ & 0.119 \\
\hline 2 & 5 & 10 & 200 & 1790 & $\begin{array}{c}0.318 \\
0.33\end{array}$ & 0.324 \\
\hline 3 & 10 & 20 & 200 & 1780 & $\begin{array}{l}0.459 \\
0.451\end{array}$ & 0.455 \\
\hline 4 & 20 & 40 & 200 & 1760 & $\begin{array}{l}0.760 \\
0.752\end{array}$ & 0.756 \\
\hline 5 & 25 & 50 & 200 & 1750 & $\begin{array}{l}0.841 \\
0.853\end{array}$ & 0.847 \\
\hline Control & 0 & 0 & 200 & 1800 & $\begin{array}{l}0 \\
0\end{array}$ & 0 \\
\hline
\end{tabular}

Stock Solution $(\mu \mathrm{g} / \mu \mathrm{l})$. 